\title{
Influenza A IgG Antibody Measurement
}

National Cancer Institute

\section{Source}

National Cancer Institute. Influenza A Ig G Antibody Measurement. NCI Thesaurus. Code C103408.

The determination of the amount of the Influenza A IgG antibody in a sample. 